\title{
PERTUMBUHAN DAN MORTALITAS IKAN TUNA MATA BESAR (Thunnus obesus) DI SAMUDERA HINDIA YANG DIDARATKAN DI PELABUHAN BENOA, DENPASAR, BALI
}

\author{
Growth and Mortality Bigeye Tuna (Thunnus obesus) In Indian Ocean Were Landed In Benoa Harbour, \\ Denpasar, Bali
}

\author{
Erika Kurniawati $S^{1}$, Abdul Ghofar*)1, Suradi Wijaya Saputra ${ }^{1}$, Budi Nugraha² \\ ${ }^{1}$ Program Studi Manajemen Sumberdaya Perairan, Departemen Sumberdaya Akuatik \\ Fakultas Perikanan dan Ilmu Kelautan, Universitas Diponegoro, Semarang \\ ${ }^{2}$ Peneliti pada Loka Penelitian Perikanan Tuna Denpasar, Bali \\ ${ }^{1}$ Jl. Prof. Soedarto, SH, Tembalang, Semarang, Jawa Tengah - 50275, Telp/Fax. +6224 7474698 \\ ${ }^{2}$ Jl. Mertasari No.140, Br. Suwung Kangin, Sidakarya, Denpasar Selatan, Bali - 80223, Fax. +62361 8497447 \\ Email : erikakurnia81@gmail.com
}

\begin{abstract}
ABSTRAK
Tuna mata besar (Thunnus obesus) di Samudera Hindia menjadi salah satu target utama penangkapan. Berdasarkan pemanfaatan tersebut, perlu dilakukan penelitian mengenai parameter populasi tuna mata besar. Penelitian ini bertujuan untuk mengetahui aspek pertumbuhan, ukuran pertama kali tertangkap, parameter populasi, laju mortalitas, laju eksploitasi dan pola rekrutmen. Jumlah sampel tuna mata besar sebanyak 648 ekor diambil dari 21 armada rawai tuna (longline) yang melakukan bongkar selama penelitian. Data panjang tahun 2013-2014 diperoleh dari Loka Penelitian Perikanan Tuna Bali. Penelitian ini dilakukan bulan April-Mei 2016 di Pelabuhan Benoa, Denpasar, Bali. Analisis data menggunakan Model Von Bertalanffy Growth Function dengan software FISAT II. Hasil penelitian menunjukkan pola pertumbuhan bersifat allometrik negatif. Faktor kondisi diperoleh sebesar 1,02-1,27. Ukuran pertama kali tertangkap $\left(\mathrm{L}_{50 \%}\right)$ sebesar 126,54 cmFL. Persamaan pertumbuhan Von Bertalanffy Growth Function (VBGF) diperoleh $\mathrm{L}_{\mathrm{t}}=199,5\left(1-\mathrm{e}^{0,22(\mathrm{t}+0,451)}\right)$, dengan nilai $\mathrm{K}=$ 0,22/tahun, nilai $\mathrm{t}_{0}=-0,451$ tahun dan $\mathrm{L}_{\infty}=199,5 \mathrm{cmFL}$. Laju mortalitas penangkapan $(\mathrm{F})=0,51 /$ tahun, lebih besar daripada mortalitas alami $(\mathrm{M})=0,40 /$ tahun, berarti kematian tuna mata besar lebih banyak disebabkan karena faktor eksploitasi/penangkapan. Laju eksploitasi $(\mathrm{E})=0,56$ mengindikasikan tuna mata besar yang tertangkap oleh armada rawai tuna (longline) di Samudera Hindia dalam kondisi fully exploited (padat tangkap). Kata Kunci : Ikan tuna mata besar; aspek biologi; umur; pertumbuhan; mortalitas; laju eksploitasi; rekrutmen;

Samudera Hindia
\end{abstract}

\begin{abstract}
Bigeye tuna (Thunnus obesus) in the Indian Ocean became one of the main targets of arrest. Based on utilization, research is needed on bigeye tuna population parameters. This study aims to determine of growth, size at the first caught, population parameters, mortality rate, exploitation rate and recruitment patterns. Number samples of bigeye tuna were taken from 648 fishes by 21 tuna longline fleets which was unloading during this study. Length data of 2013-2014 were obtained from Research Institute for Tuna Fisheries, Bali. This research was conducted April-May 2016 in Benoa Harbour, Denpasar, Bali. Data analysis used the Von Bertalanffy Growth Function Model with FISAT II software. The results showed negative allometric growth patterns. The condition factor was obtained for 1.02 to 1.27 . The length at first caught (L50\%) amounted to $126.54 \mathrm{cmFL}$. VBGF growth equation was obtained $L_{t}=199.5\left(1-e^{0.22(t+0.451)}\right)$, with the value $K=0,22 /$ year, $t_{0}=$ $-0,451 / y e a r$ and $L_{\infty}=199,5 \mathrm{cmFL}$. The fishing mortality rate $(F)=0.51 /$ year, it was bigger than the natural mortality $(M)=0.40 /$ year, means that mostly mortality of bigeye tuna was caused by the exploitation / fishing factor. The exploitation rate $(E)=0.56$, indicated that bigeye tuna were caught by tuna longline fleets in the Indian Ocean on fully exploited.
\end{abstract}

Keywords:Bigeye tuna; biology aspect; age; growth; mortality; exploitation rate; recruitment; Indian Ocean

*) Penulis penanggungjawab

${ }^{\circledR}$ Copyright by Management of Aquatic Resources (MAQUARES) 


\section{Pendahuluan}

Samudera Hindia merupakan salah satu perairan laut Indonesia yang menjadi perhatian masyarakat perikanan dunia, terutama terkait dengan sumberdaya ikan tuna. Data produksi tuna enam tahun terakhir menempatkan Indonesia sebagai negara penghasil tuna terbesar kedua di dunia. Berdasarkan kondisi diatas, sebagai salah satu konsekuensi logis, Indonesia tergabung dalam lembaga pengelolaan sumberdaya ikan regional seperti IOTC (Indian Ocean Tuna Commision) dan CCSBT (Commision for Conservation of Southern Bluefin Tuna) maupun lembaga lainnya yang diperlukan untuk pengumpulan data yang komprehensif. Sampai saat ini kelembagaan yang sangat berperan dalam dukungan data bagi kerjasama IOTC dan CCSBT adalah Loka Penelitian Perikanan Tuna Benoa yang lokasinya berada di Pelabuhan Benoa, Bali (Loka Penelitian Perikanan Tuna Benoa, 2008). Pemanfaatan sumberdaya ikan tuna mata besar di Samudera Hindia saat ini telah memperlihatkan suatu peningkatan, hal ini dapat dilihat dari hasil tangkapan yang cenderung menurun sejak akhir tahun 1990-an. Hasil tangkapan ikan tuna mata besar dengan longline di Samudera Hindia dari akhir tahun 1980-an hingga awal tahun 1990-an meningkat dari 40.000 ton hingga mencapai 100.000 ton. Puncak hasil tangkapan terjadi pada tahun 1997-1999 (140.000-150.000 ton) dan sejak saat itu terjadi penurunan yaitu 96.200-121.700 ton pada tahun 2003-2007 (IOTC, 2008). Seiring dengan upaya pemanfaatan ikan tuna di Samudera Hindia dari tahun ke tahun cenderung mengalami peningkatan, perlu dilakukan konsep pengelolaan yang tepat dalam jangka panjang guna menjamin tangkapan yang menguntungkan tetapi kelestarian sumberdaya ikan tuna tetap terjaga. Informasi yang diperlukan untuk mengetahui kondisi populasi tuna mata besar adalah dengan menggunakan metode pendugaan pertumbuhan dan mortalitas ikan tuna mata besar berdasarkan data frekuensi panjang.

Tujuan dari penelitian ini adalah untuk mengetahui kondisi sumberdaya ikan tuna mata besar di Samudera Hindia yang berbasis di Pelabuhan Benoa dilihat dari aspek biologi yaitu aspek pertumbuhan terdiri dari struktur ukuran, panjang berat, faktor kondisi dan ukuran pertama kali tertangkap dan parameter populasi yang terdiri dari panjang asimtotik $\left(\mathrm{L}_{\infty}\right)$, koefisien pertumbuhan $(\mathrm{K})$, laju mortalitas, laju eksploitasi $(\mathrm{E})$ dan rekrutmen, sehingga diharapkan dapat memberikan usulan atau rekomendasi untuk pengelolaan perikanan tuna.

\section{MATERI DAN METODE PENELITIAN}

Alat

Alat yang digunakan dalam penelitian diantaranya timbangan dengan ketelitian $0,1 \mathrm{~kg}$ yang digunakan untuk mengukur berat ikan tuna mata besar, kaliper dengan ketelitian $1 \mathrm{~cm}$ yang digunakan untuk mengukur panjang ikan tuna mata besar, lembar data digunakan dalam pencatatan data sampling di Pelabuhan Benoa, dan kamera untuk mendokumentasikan proses penelitian.

Bahan

Bahan yang digunakan dalam penelitian ini adalah sampel ikan tuna mata besar yang didaratkan di Pelabuhan Benoa, Denpasar, Bali.

\section{Metode Penelitian}

Metode yang digunakan dalam penelitian ini adalah metode survei, yaitu melakukan kegiatan enumerasi pada sekitar 16 perusahaan tuna di Pelabuhan Benoa, Bali. Pengukuran berat dilakukan pada semua ikan tuna mata besar kategori ekspor maupun reject (non ekspor). Data panjang diukur berdasarkan kategori reject (non ekspor). Jumlah sampel selama penelitian sebanyak 648 ekor tuna mata besar.

Analisis Data

Hubungan Panjang Berat dan Faktor Kondisi

Menurut Effendie (2002), analisis hubungan panjang berat menggunakan persamaan sebagai berikut :

Keterangan : $\quad$ W $=$ berat tubuh $($ gram)

$$
\mathrm{W}=\mathrm{aL}^{\mathrm{b}}
$$

$\mathrm{L}=$ panjang karapas $(\mathrm{mm})$

$\mathrm{a}=$ Intercept

$\mathrm{b}=$ Slope

Untuk menguji nilai $\mathrm{b}=3$ atau $\mathrm{b} \neq 3$ dilakukan $\mathrm{t}$ uji (uji parsial), dengan hipotesis :

$\mathrm{H} 0: \mathrm{b}=3$, hubungan panjang dengan berat adalah isometrik

$\mathrm{H} 1: \mathrm{b} \neq 3$, hubungan panjang dengan berat adalah allometrik, yaitu :

Allometrik positif jika $\mathrm{b}>3$ (pertambahan berat lebih cepat daripada pertambahan panjang) dan Allometrik negatif jika $\mathrm{b}<3$ (pertambahan panjang lebih cepat daripada pertambahan berat).

Perhitungan faktor kondisi (Ponderal Index) berdasarkan pada data panjang dan berat. Menurut Effendie (1987) dalam Saputra (2008), karena $b \nRightarrow$, perhitungan menggunakan rumus :

Keterangan:

$$
\mathrm{K}_{\mathrm{TL}}=\mathrm{W}(\text { gram }) / \mathrm{aL}^{\mathrm{b}}(\mathrm{mm})
$$

$\mathrm{K}_{\mathrm{TL}}=$ Faktor Kondisi

$\mathrm{W}=$ Berat rata-rata sesungguhnya

$\mathrm{W}^{\prime}=$ Berat rata-rata perhitungan $\left(\mathrm{aL}^{\mathrm{b}}\right)$

\footnotetext{
${ }^{\circledR}$ Copyright by Management of Aquatic Resources (MAQUARES)
} 


\section{Ukuran Pertama Kali Tertangkap (L50\%)}

Menurut King (1995), ukuran pertama kali tertangkap dapat dihitung dengan kurva logistik berbentuk sigmoid dengan rumus :

$$
\mathrm{L}_{50 \%}=\mathrm{a} / \mathrm{b}
$$

Keterangan : $\quad \mathrm{L}_{50 \%}=$ Ukuran pertma kali tertangkap $(\mathrm{cm})$

$$
\begin{aligned}
& \mathrm{a}=\text { Intersep } \\
& \mathrm{b}=\text { slope }
\end{aligned}
$$

Keterangan : $\quad \mathrm{P}=$ Proporsi

$$
\mathrm{P}=1 /\left(1+\exp \left[-\mathrm{r}\left(\mathrm{L}-\mathrm{L}_{50 \%}\right)\right]\right)
$$

$\mathrm{r}=0,775$

$\mathrm{L}=$ Panjang

$\mathrm{L}_{50 \%}=$ ukuran pertama kali terangkap

Nilai $r$ konstan dengan nilai yang mengalami kenaikan dengan kurva seleksi, dan $\mathrm{L}_{50 \%}$ berarti panjang pertama kali tertangkap.

\section{Pendugaan Parameter Pertumbuhan}

Perhitungan persamaan pertumbuhan menggunakan metode non-parametric Scoring of VBGF Fit Using ELEFAN I (electro length frequency analysis) yang terdapat dalam paket program FISAT II dengan memasukkan data interval panjang dalam bentuk .lfq (grouped frequencies). $\mathrm{L} \infty$ dapat diduga menggunakan rumus Pauly (1984) dengan rumus:

$$
\mathrm{L} \infty=\mathrm{L}_{\text {maks }} / 0,95
$$

Keterangan: $\quad \mathrm{L}_{\text {maks }}=$ panjang sampel tertinggi yang didapatkan

Penentuan nilai $t_{0}$ menurut Saputra (2008) menggunakan rumus empiris Pauly dengan menggunakan hubungan regresi berganda antara umur teoritis saat panjang ikan nol $\left(\mathrm{t}_{\mathrm{o}}\right)$ dengan panjang infinity $(\mathrm{L} \infty)$ dan $\mathrm{K}$, yaitu sebagai berikut:

Keterangan:

$$
\log -\mathrm{t}_{0}=-0,3952-0,2752 \log \mathrm{L} \infty-1,038 \log \mathrm{K}
$$

$\mathrm{L} \infty=$ Panjang infiniti $(\mathrm{cm})$

$\mathrm{K}=$ Koefisien pertumbuhan Von Bertalanffy

Laju pertumbuhan diduga dengan model von Bertalanffy (Gulland, 1983) dengan rumus sebagai berikut:

$$
\mathrm{Lt}=\mathrm{L} \infty\left(1-\mathrm{e}^{-\mathrm{K}(\mathrm{t}-\mathrm{0})}\right)
$$

Keterangan : $\quad L t=$ Panjang ikan pada umur $\mathrm{t}(\mathrm{cm})$

$\mathrm{L} \infty=$ Panjang infiniti $(\mathrm{cm})$

$\mathrm{t}_{\mathrm{o}}=$ Umur teoritis ikan pada panjang 0

\section{Pendugaan Laju Mortalitas}

$\mathrm{K}=$ Koefisien pertumbuhan Von Bertalanffy

Penghitungan nilai $\mathrm{Z}$ (mortalitas total) didapatkan dengan menggunakan metode kurva tangkapan yang dikonversi ke panjang, dalam paket program FISAT II. Rumus penghitungan nilai Z yang dikembangkan oleh Beverton dan Holt (1956), Powell (1979) dan terakhir oleh Wetherall (1986) dan Wetherall et al (1987) dalam Saputra (2008) adalah sebagai berikut:

Keterangan:

$$
\begin{aligned}
& \qquad \mathrm{Z}=\mathrm{K}\left[\left(\mathrm{L}_{\infty}-\right) /\left(-\mathrm{I}^{\prime}\right)\right] \\
& \mathrm{Z}=\text { mortalitas total } \\
& \mathrm{K}=\text { indeks kurva pertumbuhan von Bertalanffy } \\
& \mathrm{L} \infty=\text { panjang infiniti } \\
& \quad=\text { rata-rata panjang ikan dalam kelomok umur tertentu } \\
& \mathrm{I}^{\prime}=\text { = panjang ikan terkecil dalam sampel }
\end{aligned}
$$

M (mortalitas alami) dihitung berdasarkan rumus empiris Pauly (1984) dengan memasukkan parameter $\mathrm{K}$ per tahun, $\mathrm{L} \infty(\mathrm{mm})$, dan $\mathrm{T}$ (rata-rata suhu permukaan air tahunan dalam derajat Celcius). Rumus empiris Pauly adalah sebagai berikut:

$$
\log M=-0,0066-0,279 \log L \infty+0,6543 \log K+0,4634 \log T
$$

Keterangan: $\quad \mathrm{M}=$ Koefisien mortalitas alami

$$
\mathrm{L} \infty=\text { Panjang infiniti }(\mathrm{cm})
$$

$\mathrm{K}=$ Koefisien pertumbuhan Von Bertalanffy

$\mathrm{T}=$ Suhu rata - rata perairan Samudera Hindia diasumsikan $28,6^{\circ} \mathrm{C}$ (Setyadji, 2015)

Mortalitas penangkapan $(\mathrm{F})$ dapat dihitung dengan mengurangkan mortalitas total $(\mathrm{Z})$ terhadap mortalitas alami (M), dengan rumus di bawah ini:

Keterangan:

$$
\mathrm{Z}=\mathrm{F}+\mathrm{M} \text {, menjadi: } \mathrm{F}=\mathrm{Z}-\mathrm{M}
$$

$\mathrm{F}=$ Koefisien mortalitas penangkapan

$\mathrm{M}=$ Koefisien mortalitas alami

Berdasarkan nilai dugaan laju mortalitas akibat penangkapan (F) dibagi dengan laju mortalitas total (Z), maka laju eksploitasi (E) dapat diduga dengan rumus berikut:

$$
\mathrm{E}=\mathrm{F} / \mathrm{Z}
$$

\footnotetext{
${ }^{\circledR}$ Copyright by Management of Aquatic Resources (MAQUARES)
} 
Keterangan:

$\mathrm{E}=$ Laju eksploitasi (bagian dari mortalitas yang disebabkan oleh penangkapan).

$\mathrm{F}=$ Mortalitas penangkapan

$\mathrm{Z}=$ Mortalitas total

Jika nilai $\mathrm{E}=0,5$ menunjukkan bahwa nilai tersebut optimum $\left(\mathrm{E}_{\mathrm{opt}}\right)$, hal ini didasarkan pada asumsi bahwa hasil berimbang adalah optimum bila F=M (Gulland 1971 dalam Pauly 1987).

Pola rekrutmen

Pola rekrutmen didapatkan menggunakan program FISAT II pada sub program recruitmen pattern. Program tersebut akan menampilkan persentase rekruitmen selama penelitian. Hasil dari pendugaan berupa histogram dengan memasukkan file dengan format .lfq (grouped frequencies) yang akan digunakan kemudian memasukkan nilai $\mathrm{L} \infty, \mathrm{K}$, dan $\mathrm{t}_{\mathrm{o}}$ yang telah dihitung sebelumnya.

\section{HASIL DAN PEMBAHASAN}

\section{Hubungan Panjang Berat dan Faktor Kondisi}

Analisa hubungan panjang berat berdasarkan data 648 ekor sampel ikan tuna mata besar hasil tangkapan longline yang didaratkan di Pelabuhan Benoa Bali tersaji pada Gambar 1.

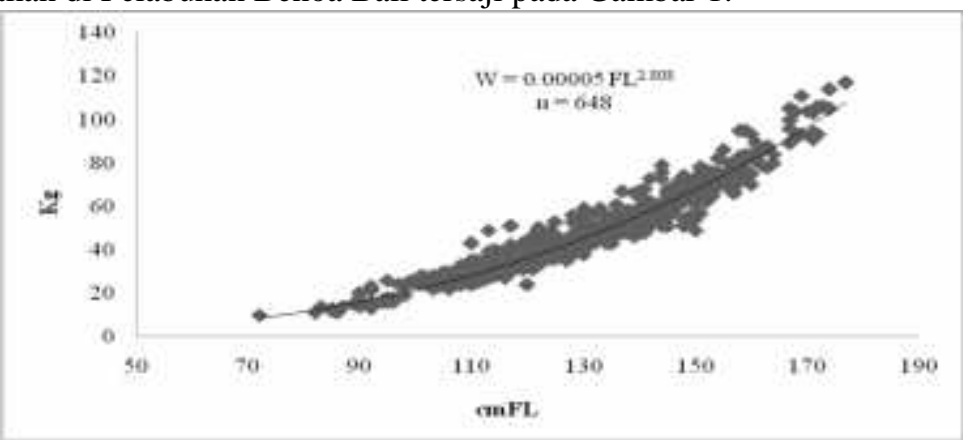

Gambar 1. Grafik hubungan panjang berat tuna mata besar yang didaratkan di Pelabuhan Benoa, 2016

Analisa hubungan panjang berat tuna mata besar didapatkan persamaan eksponensial $\mathrm{W}=0,00005 \mathrm{FL}^{2,808}$. Persamaan tersebut memunculkan nilai intersep sebesar a=0,00005 dan koefisien regresi (slope) sebesar $\mathrm{b}=2,808$. Nilai koefisien regresi kurang dari 3, maka pola pertumbuhan ikan tuna mata besar dari Samudera Hindia yang didaratkan di Pelabuhan Benoa bersifat allometrik negatif, artinya bahwa pertambahan panjang tubuh lebih cepat daripada pertambahan beratnya. Penelitian yang dilakukan oleh Zhu et al. (2008) di tiga perairan, yaitu Samudera Atlantik dan Hindia selama periode 2002 sampai 2006 mendapatkan hasil allometrik negatif untuk tuna mata besar dengan persamaan $\mathrm{W}=0,0000158 \mathrm{FL}^{2,997}$ (Atlantik), W=0,0000247FL ${ }^{2,926}$ (Hindia). Sedangkan di Samudera Pasifik bagian timur didapatkan sifat pertumbuhan allometrik positif dengan persamaan $\mathrm{W}=0,0000132 \mathrm{FL}^{3,043}$.Menurut pendapat Tesch (1971); Bagenal dan Tesch (1978) yang dikutip oleh Zhu et al. (2010), hubungan panjang berat pada ikan dipengaruhi oleh beberapa faktor, diantaranya adalah musim, habitat, ketersediaan makanan, kecepatan makan, perkembangan gonad, jenis kelamin, masa pemijahan, kondisi kesehatan tubuh ikan. Pendapat lain dari hasil penelitian Faizah (2010), menjelaskan bahwa pertumbuhan ikan tuna di suatu perairan banyak dipengaruhi oleh faktor lingkungan diantaranya adalah ukuran makanan yang dimakan, jumlah ikan di perairan tersebut, jenis makanan yang dimakan, kondisi oseanografi perairan (suhu, oksigen, dan lain-lain) dan kondisi ikan (umur, keturunan, dan genetik).

Nilai faktor kondisi tidak mempunyai arti jika hanya berdiri sendiri pada satu individu, sehingga diperlukan perbandingan nilai faktor kondisi dengan individu lain. Berikut grafik perbandingan nilai faktor kondisi tuna mata besar (Gambar 2).

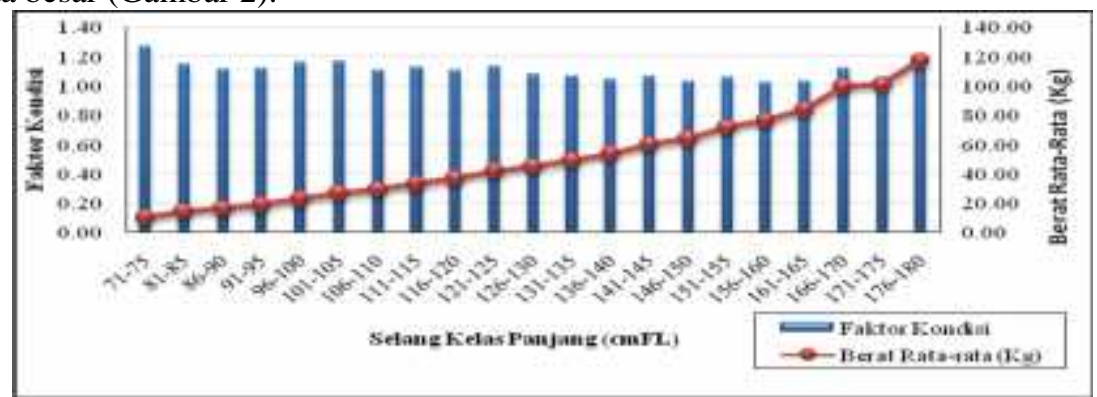

Gambar 2. Hubungan faktor kondisi dengan berat rata-rata tuna mata besar di Samudera Hindia

(April-Mei $2016 ; \mathrm{n}=648$ )

Nilai faktor kondisi dari tuna mata besar antara 1,02 - 1,27. Nilai faktor kondisi dari spesies tuna lain seperti ikan sirip kuning yang ditangkap pada bulan Maret-April di Samudera Hindia memiliki nilai antara

\footnotetext{
${ }^{\circledR}$ Copyright by Management of Aquatic Resources (MAQUARES)
} 
1,63 - 1,95 dan untuk tuna sirip biru memiliki nilai antara $1,83-2,08$. Nilai faktor kondisi pada ketiga speseies tuna dari hasil tangkapan di Samudera Hindia ini relatif tidak berbeda. Ikan tuna sirip biru memiliki kondisi tubuh yang paling baik dengan tingkat kegemukan (kemontokan) relatif lebih tinggi dibandingkan tuna sirip kuning dan tuna mata besar. Menurut Faizah (2010), nilai faktor kondisi tuna mata besar di Samudera Hindia selama bulan Maret hingga Oktober 2008 diperoleh pada kisaran 1,915 - 2,038 dengan ratarata 1,951. Sedangkan penelitian yang dilakukan Wang et al. (2002) di sekitar perairan Taiwan mendapatkan nilai kisaran untuk faktor kondisi antara 1,4 - 2,5. Menurut Effendie (2002), variasi nilai faktor kondisi itu tergantung kepada makanan, umur, jenis, seks dan kematangan gonad.

\section{Struktur Ukuran dan Ukuran Pertama Kali Tertangkap}

Ukuran panjang ikan tuna mata besar yang didapatkan selama penelitian berkisar antara $72-177 \mathrm{cmFL}$ dari data 648 ekor sampel ikan. Gambar frekuensi panjang ikan tuna mata besar yang tertangkap tersaji pada Gambar 3 .

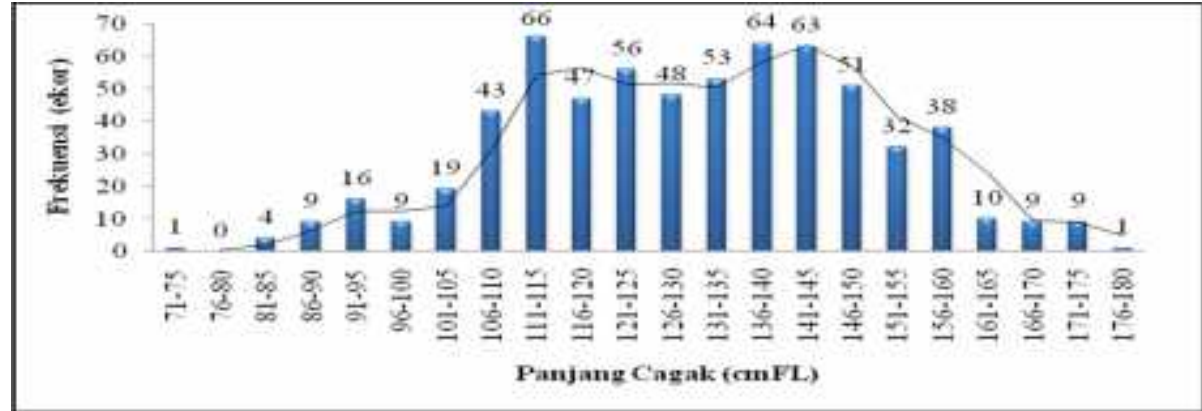

Gambar 3. Sebaran panjang cagak tuna mata besar hasil tangkapan tuna longline yang didaratkan di Pelabuhan Benoa, 2016

Bulan April-Mei 2016 selama penelitian didapatkan ukuran minimum $\left(\mathrm{L}_{\mathrm{min}}\right)$ yang tertangkap adalah 72 cmFL, ukuran maksimum $\left(\mathrm{L}_{\max }\right)$ adalah $177 \mathrm{cmFL}$ dengan rata-rata ukuran yang tertangkap 130,28 cmFL. Ukuran paling banyak tertangkap pada rentang 111-115 cmFL sebanyak 66 ekor dengan $112 \mathrm{cmFL}$ yang paling mendominasi sebanyak 16 ekor. Ukuran panjang rata-rata ikan dari hasil penelitian ini cenderung sama dengan penelitian yang dilakukan sebelumnya oleh Faizah (2010) di Samudera Hindia pada Maret hingga Oktober 2008 dengan ukuran panjang cagak antara $109-153 \mathrm{~cm}$ dan rata-rata $130,4 \mathrm{~cm}$.

Ukuran pertama kali tertangkap $\left(\mathrm{L}_{50 \%}\right)$ tuna mata besar selama penelitian (April-Mei 2016) dari tangkapan di Samudera Hindia adalah 126,54 cmFL (Gambar 4).

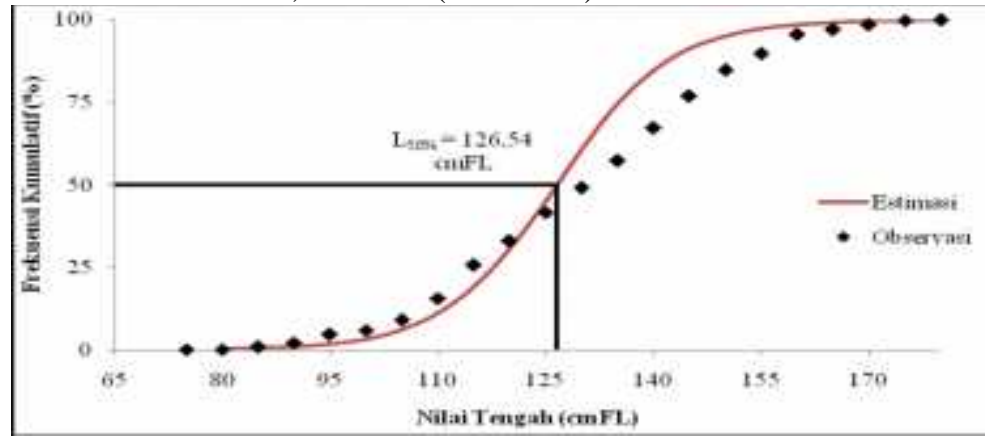

Gambar 4. Ukuran rata-rata panjang cagak pertama kali tertangkap tuna mata besar

Data ukuran pertama kali tertangkap $\left(\mathrm{L}_{50 \%}\right)$ dan ukuran pertama kali matang gonad $\left(\mathrm{L}_{\mathrm{m} 50 \%}\right)$ dari beberapa lokasi penelitian dapat dilihat pada Tabel 1.

Tabel 1. Ukuran Pertama Kali Tertangkap $\left(\mathrm{L}_{50 \%}\right)$ dan Ukuran Pertama Kali Matang Gonad ( $\mathrm{L}_{\mathrm{m} 50 \%}$ ) Ikan Tuna Mata Besar pada Beberapa Lokasi

\begin{tabular}{|c|c|c|c|c|c|c|}
\hline \multirow{2}{*}{ Lokasi } & \multicolumn{2}{|c|}{$\mathbf{L}_{50 \%}(\mathbf{c m})$} & \multicolumn{3}{|c|}{$\mathbf{L}_{\mathrm{m50}} \%(\mathbf{c m})$} & \multirow{2}{*}{ Sumber } \\
\hline & Betina & Jantan & Betina & Jantan & Unsexed & \\
\hline Atlantik & 117,7 & 119,5 & 104 & 108 & - & $\begin{array}{l}\text { Penelitian yang dilakukan } \\
\text { Zhu et al. }(\text { (2011) }\end{array}$ \\
\hline \multirow[t]{2}{*}{ Pasifik } & - & - & - & - & 99,7 & Sun et al. (2006) \\
\hline & 117,5 & - & - & 94 & - & $\begin{array}{l}\text { Penelitian yang dilakukan Zhu } \\
\text { et al. (2011) }\end{array}$ \\
\hline Hindia & 119,5 & 117,7 & 110 & 110 & - & $\begin{array}{l}\text { Penelitian yang dilakukan Zhu } \\
\text { et al. (2011) }\end{array}$ \\
\hline Hindia & $126,54(l$ & exed) & - & - & - & Hasil penelitian (2016) \\
\hline
\end{tabular}

Sumber : Penelitian Zhu et al. (2011) 
Hasil perhitungan ukuran pertama kali tertangkap $\left(\mathrm{L}_{50 \%}\right)$ selama penelitian sebesar 126,54 cmFL, ukuran pertama kali matang gonad $\left(\mathrm{L}_{\mathrm{m} 50 \%}\right)$ di Samudera Hindia oleh penelitian Zhu et al. (2011) sebesar 110 cmFL, dan nilai $1 / 2 \mathrm{~L} \infty$ untuk ikan tuna mata besar selama penelitian (April-Mei 2016) sebesar 93,16 cmFL. Nilai $\mathrm{L}_{50 \%}>\mathrm{L}_{\mathrm{m} 50 \%}$, menunjukkan bahwa ikan tuna mata besar yang tertangkap di Samudera Hindia sebagian besar telah memijah, sehingga aman untuk dilakukan penangkapan. Hal tersebut dikarenakan rata-rata ukuran ikan pertama kali tertangkap telah melewati matang gonad sehingga diduga telah melakukan reproduksi.

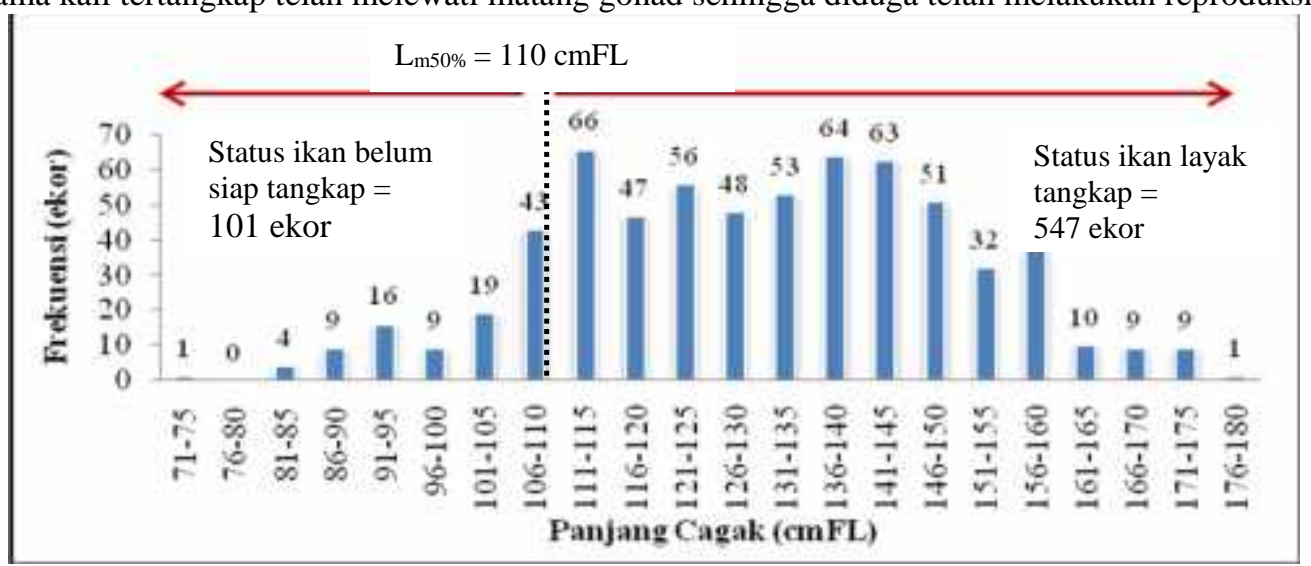

Gambar 5. Histogram rekomendasi status stok ikan tuna mata besar di Samudera Hindia

Berdasarkan Gambar 5, pembatasan ukuran layak tangkap dapat ditentukan dengan mengacu pada batas ukuran pertama kali matang gonad $\left(\mathrm{L}_{\mathrm{m} 50 \%}\right)$. Ikan tuna mata besar di Samudera Hindia hampir $85 \%$ dengan jumlah 547 ekor, diduga tergolong dalam ukuran layak tangkap dari total 648 ekor sampel ikan selama penelitian.

\section{Laju Pertumbuhan}

Panjang infiniti $\left(\mathrm{L}_{\infty}\right)$ dan koefisien pertumbuhan tuna mata besar pada tahun 2013 sampai 2014 masingmasing sebesar 199,5 cmFL dan 0,22 per tahun. Panjang infiniti ini menunjukkan bahwa secara teoritis panjang tuna mata besar akan berhenti pada ukuran 199,5 cmFL walaupun umurnya terus bertambah. Nilai koefisian pertumbuhan $\mathrm{K}=0,22$ per tahun menunjukkan bahwa laju pertumbuhan relatif lambat. Kikkawa dan Cushing (2002) menyatakan bahwa laju pertumbuhan tuna mata besar selama setahun dapat digolongkan cepat apabila ( $\mathrm{K}>0,3$ per tahun) dan lambat apabila $\left(\mathrm{K}<0,3\right.$ per tahun). Nilai $\mathrm{t}_{0}$ tuna mata besar dari Samudera Hindia sebesar -0,451 ini artinya bahwa umur tuna mata besar (semu) atau secara teoritis pada panjang $0 \mathrm{~cm}$ diduga sebesar -0,451 tahun. Penelitian sebelumnya yang dilakukan oleh Stequert dan Conand (2004) di Samudera Hindia bagian barat, nilai $\mathrm{L}_{\infty}$ sebesar 169,06 cmFL dan nilai koefisien pertumbuhan sebesar 0,32 per tahun dengan nilai $\mathrm{t}_{0}$ sebesar -0,34. Nilai koefisien pertumbuhan dari hasil penelitian menunjukkan angka yang lebih lambat dibandingkan penelitian oleh Stequert dan Conand (2004). Penelitian lain yang dilakukan di Samudera Atlantik bagian timur oleh Hallier et al. (2005) mendapatkan nilai panjang infiniti $\left(\mathrm{L}_{\infty}\right)$ didapatkan sebesar 207,43 cmFL dengan nilai koefisien pertumbuhan $(\mathrm{K})$ sebesar 0,202 per tahun dan nilai $\mathrm{t}_{0}$ sebesar $-0,613$. Nilai tersebut tidak jauh berbeda dengan hasil selama penelitian berlangsung.Dari persamaan tersebut kemudian dapat dilakukan perhitungan mundur untuk mengetahui grafik perbandingan umur dan pertumbuhan tuna mata besar (Gambar 7).

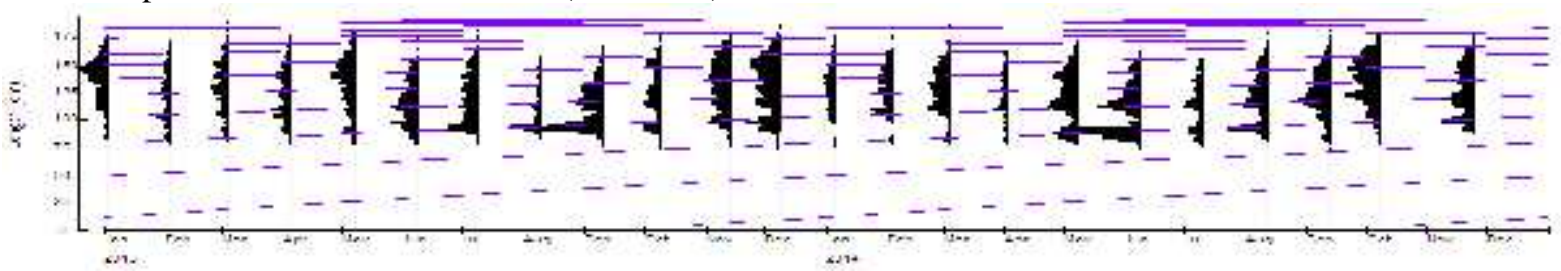

Gambar 6. Sebaran frekuensi panjang cagak dan kurva pertumbuhan tuna mata besar di Samudera Hindia,

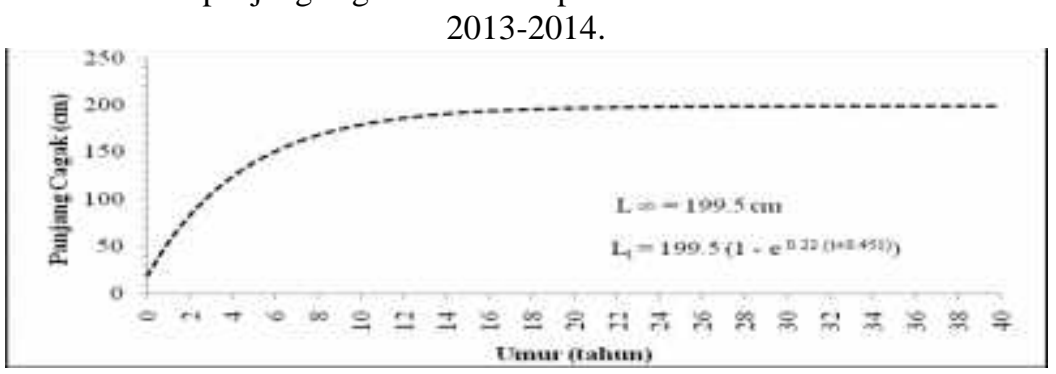

Gambar 7. Kurva pola pertumbuhan von bertalanffy ikan tuna mata besar di Samudera Hindia (2013-2014)

\footnotetext{
(C) Copyright by Management of Aquatic Resources (MAQUARES)
} 


\section{Laju Mortalitas dan Laju Eksploitasi}

Hasil pengoperasian FISAT II berdasarkan nilai $\mathrm{K}$ dan $\mathrm{L} \infty$ yang diperoleh dari metode length-converted catch curve. Kurva pendugaan nilai mortalitas dan eksploitasi tersaji pada Gambar 8.

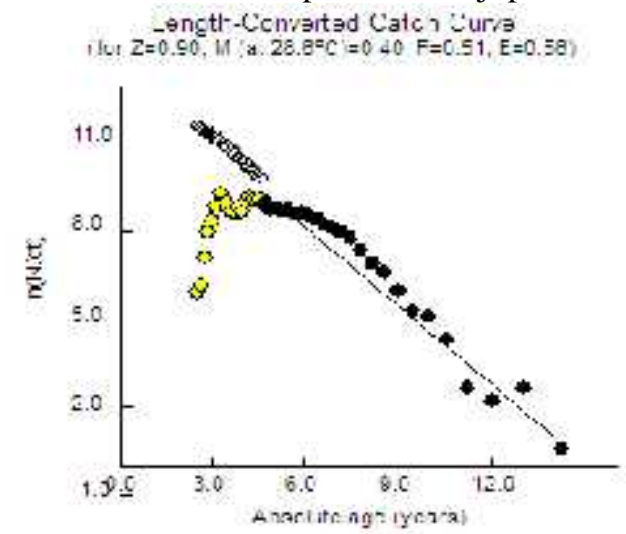

Gambar 8. Kurva hasil tangkapan untuk menduga nilai mortalitas dan eksploitasi (2013-2014).

Keterangan: titik hitam= titik data dalam kurva yang digunakan dalam regresi.

Laju mortalitas alami (M) tuna mata besar di Samudera Hindia dalam penelitian ini sebesar 0,4 per tahun. Penelitian yang dilakukan Riswanto (2012) di Samudera Hindia selatan menunjukkan laju mortalitas alami yang lebih tinggi yaitu sebesar 0,61629 per tahun. Laju mortalitas dalam penelitian ini relatif sama dengan laju mortalitas alami di Samudera Atlantik bagian tengah sebesar 0,39 (Zhu et al., 2009). Nilai M ini mempunyai hubungan dengan kondisi fisik tuna mata besar dan lingkungan perairan. Menurut Sparre dan Venema (1999), nilai M akan bergantung pada penyakit, stres, pemijahan, kelaparan, usia tua, serta menurut Beverton dan Holt (1957), disebabkan karena predasi. Laju mortalitas penangkapan selama penelitian sebesar $\mathrm{F}=0,51$. Sedangkan laju mortalitas dalam penelitian sebelumnya di Samudera Hindia diperoleh nilai $\mathrm{F}=0,08571$ (Riswanto, 2012). Nilai tersebut jauh lebih kecil dari hasil selama penelitian, diduga upaya penangkapan pada penelitian sebelumnya masih tergolong minimum (under exploited).

Hasil penelitian menunjukkan laju eksploitasi (E) sebesar 0,56. Kondisi tersebut dapat dijelaskan menurut kriteria Pauly, bahwa tuna mata besar di Samudera Hindia selama penelitian sudah melebihi batas lestari yang ditentukan. Meskipun hanya melebihi $6 \%$ dari total maksimum pemanfaatan lestari sebesar 50\%, hal ini menjadi peringatan dalam pengelolaan sumberdaya tuna khususnya di wilayah perairan Indonesia. Sedangkan penelitian Riswanto (2012) di Samudera Hindia mendapatkan laju eksploitasi sebesar 0,122094. Nilai tersebut menunjukkan bahwa selama penelitian kondisi eksploitasi masih tergolong dibawah batas maksimum eksploitasi (under exploited).

\section{Pola Rekrutmen}

Pola rekrutmen didapatkan dengan memasukkan nilai $\mathrm{L} \propto, \mathrm{K}$, dan $\mathrm{t} 0$, kemudian dihitung menggunakan software FiSAT II. Hasil penghitungan persentase dari pola rekrutmen dapat dilihat pada Tabel 2.

Tabel 2. Persentase Bulanan Penambahan Baru Thunnus obesus

\begin{tabular}{lc}
\hline \multicolumn{1}{c}{ Bulan } & Persentase Rekrutmen (\%) \\
\hline Januari & 1,28 \\
Februari & 3,52 \\
Maret & 6,57 \\
April & 10,81 \\
Mei & 12,45 \\
Juni & 19,72 \\
Juli & 16,95 \\
Agustus & 14,44 \\
September & 6,81 \\
Oktober & 4,87 \\
November & 2,57 \\
Desember & 0 \\
\hline Sumber : Data panjang $2013-2014$ diolah dengan FISAT II
\end{tabular}

Sumber : Data panjang 2013-2014 diolah dengan FISAT II

Berdasarkan tabel 2, pola rekrutmen dari ikan tuna mata besar hasil tangkapan di Samudera Hindia menunjukkan bahwa terdapat satu modus selama satu tahun. Puncak modus terjadi pada bulan Juni dengan persentase hampir $20 \%$. Pola rekrutmen tuna mata besar ini berguna untuk menduga rekrutmen populasi ikan di alam yang terjadi selama setahun. 


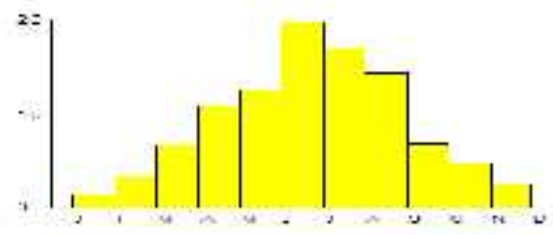

Gambar 9. Pola rekrutmen tuna mata besar di Samudera Hindia (2013-2014)

Berdasarkan hasil yang didapatkan bahwa rekrutmen ikan tuna mata besar terjadi hampir setiap bulan. Menurut Ongkers (2006), pola rekrutmen ikan memiliki keterkaitan dengan waktu pemijahan. Berdasarkan hasil yang didapatkan bahwa rekrutmen ikan tuna mata besar terjadi hampir setiap bulan. Nikaido et al. (1991) menyatakan bahwa ikan tuna mata besar merupakan serial spawner, dapat mengulang pemijahan secara harian atau mendekati interval harian selama periode pemijahan yang panjang. Nootmom (2004) menyatakan bahwa aktivitas pemijahan ikan tuna mata besar di Samudera Hindia yaitu dari bulan Desember hingga bulan Januari dan bulan Juni. Ukuran yang matang 50\% untuk ikan tuna mata besar tergantung pada rasio kelamin yang bervariasi setiap bulan. Selang ukuran kelas untuk tuna ukuran kecil $(85-115 \mathrm{cmFL})$ didominasi ikan betina, sedangkan ukuran besar (125-155 cmFL) didominasi ikan jantan. Dengan demikian, rekrutmen pada bulan Juni dari hasil penelitian diduga berasal dari pemijahan pada bulan Desember hingga Januari, sehingga pendugaan aktivitas pemijahan terjadi pada umur antara 3-7 tahun.

\section{Pengelolaan Perikanan Tuna Mata Besar}

Pengelolaan perikanan berkelanjutan atau sustainable pada saat ini telah menjadi tuntutan dalam pemanfaatan sumberdaya alam. Ikan merupakan sumber daya yang dapat dipulihkan atau renewable resources karena memiliki kemampuan untuk memulihkan dan memperbaiki stoknya di perairan. Hal tersebut dapat dicapai apabila penangkapan dilakukan dengan kaidah yang benar dengan memperhatikan beberapa aspek seperti, data biologis ikan, teknik penangkapan yang ramah lingkungan, musim penangkapan, dan lain sebagainya. Menurut Setyadji (2015), salah satu pendekatan yang dapat dilakukan adalah membatasi ukuran

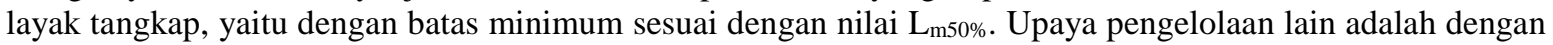
pembatasan dan pengawasan terhadap jumlah kapal rawai tuna yang beroperasi dalam upaya penangkapan tuna di Samudera Hindia. Menurut Irianto et al. (2014), total armada rawai tuna Indonesia yang terdaftar di IOTC per 26 Desember 2014 cukup besar yakni sebanyak 1.282 unit, dengan komposisi armada di atas 30 GT sebesar 1.040 unit $(81,20 \%)$. Hal ini sudah diberlakukan di Indonesia sesuai dengan Peraturan Menteri Kelautan dan Perikanan Nomor 56/PERMEN-KP/2014 tentang Penghentian Sementara (moratorium) Perizinan Usaha Perikanan Tangkap di Wilayah Pengelolaan Perikanan Negara Republik Indonesia, yaitu dengan melakukan operasi untuk menertibkan wilayah perairan Indonesia dari kapal-kapal diatas 30 GT yang masih beroperasi. Selama moratorium diberlakukan, perizinan kapal berupa izin baru mencakup Surat Izin Usaha Perikanan (SIUP), Surat Izin Penangkapan Ikan (SIPI) dan Surat Izin Kapal Pengangkut Ikan (SIKPI) akan ditangguhkan dan ditertibkan. Selanjutnya akan dilakukan analisis dan evaluasi bagi SIPI dan SIKPI yang masih berlaku.

Solusi lain pengelolaan perikanan di Indonesia khususnya untuk perikanan tuna menurut Ghofar dan Martosubroto (2015), adalah dengan monitoring dan protokol pengkajian stok ikan. Monitoring dilakukan dalam proses yang terintegrasi melalui pengumpulan informasi, analisis, perencanaa, konsultasi, pembuatan keputusan, alokasi sumberdaya ikan, dan implementasi serta penegakan hukum dari peraturan perundangundangan. Monitoring dilakukan secara terus menerus setiap tahun untuk mengevaluasi status perikanan. Protokol pengkajian stok ikan disusun oleh Komisi Nasional Pengkajian Sumber Daya Ikan (Komnas Kajiskan) dengan tujuan menjamin kualitas dari kegiatan monitoring sumberdaya yang dilakukan agar perubahan yang terjadi di alam terdeteksi melalui kegiatan ini. Kegiatan tersebut dilakukan mulai dari pengumpulan data, pengelolaan data, analisis data sampai pembuatan laporan.

Keterlibatan beberapa institusi juga berpengaruh terhadap pengelolaan perikanan. Tanpa koordinasi yang baik maka program-program yang diusulkan tidak akan diintegrasikan. Menurut Martosubroto (2012), ada hubungan saling terkait antar beberapa institusi yang dapat dijelaskan dalam gambar 9 .

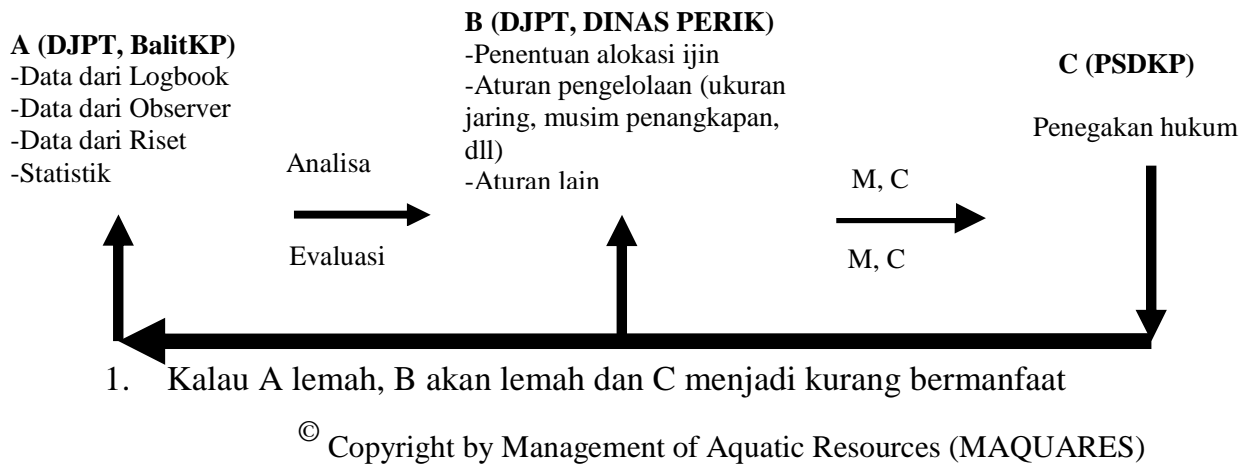

B (DJPT, DINAS PERIK)

-Penentuan alokasi ijin

Aturan pengelolaan (ukuran

Analisa dll)

Evaluasi

Copyright by Management of Aquatic Resources (MAQUARES) 
2. Kalau A kuat, B harusnya kuat dan $\mathrm{C}$ memberikan manfaat

3. Kalau A kuat, B kuat dan C lemah, mendorong A dan B akan menjadi lemah

Kwalitas kebijakan yang dirumuskan di B tergantung kepada kwalitas A da dukungan C. Tapi kalau B lemah A dan C menjadi kurang bermanfaat.

Intinya : A, B, dan C HARUS SELALU BEKERJA SAMA.

Gambar 10. Hubungan saling terkait antar beberapa institusi pengelolaan perikanan yang menentukan keberhasilan pengelolaan perikanan Indonesia ke depan (Martosubroto,2012).

\section{KESIMPULAN}

Berdasarkan penelitian yang telah dilakukan dapat diambil kesimpulan bahwa rata-rata ikan tuna mata besar yang tertangkap di Pelabuhan Benoa sudah dalam kondisi matang gonad dengan ukuran layak tangkap. Pola pertumbuhan bersifat allometrik negatif bahwa pertambahan panjang lebih cepat dibandingkan pertambahan berat tubuh. Kondisi tuna mata besar tergolong kurang pipih dilihat dari nilai faktor kondisi yang berkisar pada angka 1. Pertumbuhan ikan tuna mata besar tergolong cepat dilihat dari nilai parameter $\mathrm{K}=0,22$ /tahun dengan laju kematian penangkapan $(\mathrm{F})>(\mathrm{M})$ laju kematian alami, sehingga aktivitas penangkapan tuna mata besar di Samudera Hindia selama tahun 2013-2014 dalam kategori padat tangkap. Laju eksploitasi sudah melewati ambang batas potensi lestari sebesar $6 \%$ yang berarti kondisi penangkapan padat tangkap (fully exploited) namun belum berada pada kondisi lebih tangkap. Pola rekrutmen dari tuna mata besar terjadi hampir setiap bulan dengan puncak musim pada bulan Juni yang berkaitan dengan musim pemijahan, yaitu terjadi pada bulan sebelumnya antara Desember sampai Januari hingga Juni.

\section{DAFTAR PUSTAKA}

Amir, F., A. Mallawa., Musbir, M. Zainuddin. 2013. Dinamika Populasi Ikan Cakalang Katsuwonus pelamis (Linnaeus) di perairan Laut Flores, Sulawesi Selatan. Fakultas Ilmu Kelautan dan Perikanan Universitas Hassanudin. Makassar.

Beverton, R.J.H. and S.J. Holt. 1957. On the dynamics of exploited fish populations. Fish.Invest.Min.Agric.Fish.Food.G.B. (2. sea Fish) 19, 533 p. Reprinted 1993. chapman and Hall. Fish Fish. Ser. 11.

Effendie, M.I 2002. Biologi Perikanan. Yayasan Pustaka Nusantara. Yogyakarta. Hal 97.

Faizah, R. 2010. Biologi Reproduksi Ikan Tuna Mata Besar (Thunnus obesus) Di Perairan Samudera Hindia. Tesis Magister Sains Ilmu Kelautan Institut Pertanian Bogor.

Ghofar, A. dan P. Martosubroto. 2015. Overview Tentang Pengkajian Stok Ikan dan Pengelolaan Perikanan di Indonesia. Komisi Nasional Pengkajian Sumberdaya Ikan. Protokol Pengkajian Stok Sumber Daya Ikan. Pusat Penelitian dan Pengembangan Perikanan. Badan Penelitian dan Pengembangan Kelautan dan Perikanan. KKP. Jakarta. Hal 1-16.

Hallier J.P., B. Stequert., O. Maury., And F.X. Bard. 2005. Growth Of Bigeye Tuna (Thunnus Obesus) In The Eastern Atlantic Ocean From Tagging-Recapture Data And Otolith Readings. IRD (UR 109), CRHMT, BP 171, Av. Jean Monnet, 34203 Sète Cedex, France. IRD (US 28), Centre IRD De Bretagne, Campus IFREMER, 29280 Plouzané, France.

IOTC (Indian Ocean Tuna Commission). 2008. Preliminary growth studies of yellowfin and bigeye tuna (Thunnus albacares and T. obesus) in the Indian Ocean by otolith analysis. IOTC-2008-WPTT-30.

Kikkawa, B.S dan J.W. Cushing. 2002. Variations in Growth and Mortality of Bigeye Tuna (Thunnus obesus) in the Equatorial Western Pacific Ocean.Goverment of Guam, Department of Commerce, Business Development.

King, M. 1995. Fisheries Biology, Assessment and Management. Fishing News Books. Blackwell Science Publishing, USA. 80-92.

Loka Penelitian Perikanan Tuna (LP2T). 2010. Laporan Enumerasi Perikanan Tuna Di Pelabuhan Benoa, Bali.

Martosubroto, P. 2012. Pengelolaan Perikanan: dimana permasalahannya ? Peremuan FKPPS Nasional di Padang, 4-7 September 2012.

Nikaido, H., N. Miyabe, and S. Ueyanagi. 1991. Spawning time and frequency of Bigeye Tuna (Thunnus obesus). Bull Nat Res Inst Far Seas Fish.

\footnotetext{
${ }^{\circledR}$ Copyright by Management of Aquatic Resources (MAQUARES)
} 
Nootmom P. 2004. Reproductive biology of bigeye tuna in the eastern Indian ocean. IOTC Proceedings 2004;7 $: 1-5$.

Ongkers, O.T.S. 2006. Pemantauan Terhadap Parameter Populasi Ikan Teri Merah (Encrasicholina heteroloba) di Teluk Ambon Bagian Dalam. Prosiding Seminar Nasional Ikan IV di Jatiluhur tanggal 29-30 Agustus 2006. Masyarakat Iktiologi Indonesia kerjasama dengan Loka Riset Pemacuan Stok Ikan, PRPT-DKP, Departemen MSP-IPB, dan Puslit Biologi LIPI: 31-40.

Pauly, D. 1987. A Review of the ELEFAN System for Analysis of Length-Frequency Data in Fish and Aquatic Invertebrates. In Length-Based Methods in Fisheries Research ICLARM Conference Proceedings 13, 468p. D. Pauly and G.R. Morgan (eds). International Center for Living Aquatic Resources Management, Manila, Philippines, and Kuwait Institute for Scientific Research, Safat,Kuwait: 7 - 34p.

1984. Fish Population Dynamics in Tropical waters: A Manual for Use with Programmable Calculators. ICLARM Studies and Reviews 8. 325 p.

Riswanto, S. 2012. Status Perikanan Tuna Mata Besar (Thunnus obesus, Lowe 1839) di Perairan Samudera Hindia, Selatan Pelabuhan ratu, Sukabumi. Fakultas Matematika dan Ilmu Pengetahuan Alam. Program Magister Ilmu Kelautan. Universitas Indonesia. Depok.

Saputra, S.W. 2008. Biologi, Dinamika Populasi dan Pengelolaan Udang Metapenaeus elegans de Man 1907 di Laguna Segara Anakan Cilacap Jawa Tengah. Badan Penerbit Universitas Diponegoro Semarang.

Setyadji, B. 2015. Dinamika Populasi Ikan Pedang (Xiphias gladius L.) Di Perairan Samudera Hindia. Tesis Program Pascasarjana Universitas Udayana Denpasar.

Sparre, P. and S.C. Venema. 1999. Introduksi Pengkajian Stok Ikan Tropis. Buku 1. Manual (Edisi Bahasa Indonesia). Pus.Lit.Bang.Kan. Jakarta. 438 Hal.

Stequert, B. and F. Conand. 2004. Age and growth of Bigeye tuna (Thunnus obesus) in the Western Indian Ocean. Centre IRD de Bretagne, BP 70, 29280 Plouzané, FRANCE. Université de La Réunion, ECOMAR, 97715 St Denis cedex 9, FRANCE. 28(2): 163-170.

Wang, S.B., F.C. Chan., S.H. Wang, and C.L. Kuo. 2002. Some Biological Parameters of Bigeye and Yellowfin Tunas Distributed in Surrounding Waters of Taiwan. $15^{\text {th }}$ meeting of standing Committee on Tuna and Billfish SCTB. Hawaii. July 22-27, 2002. SCBT 15 Working paper. 13p.

Zhu G., L. Xu.,Y. Zhou.,and X. Dai. 2008. Length-Frequency Compositions And Weight-Length Relations For Bigeye Tuna, Yellowfin Tuna, And Albacore (Perciformes: Scombrinae) In The Atlantic, Indian, And Eastern Pacific Oceans. The Key Laboratory of Shanghai Education Commission for Oceanic Fisheries Resources Exploitation,College of Marine Sciences, Shanghai Ocean University, Shanghai 201306, The Key Laboratory of Sustainable Exploitation of Oceanic Fisheries Resources (Shanghai Ocean University),Ministry of Education, Shanghai 201306, ChinaChina. Tuna Fishery Technical Working Group of China, Shanghai 201306, ChinaActa Ichthyol. Piscat. 38 (2): 157-161.

Zhu, G.P., L. Xu., Y. Zhou., L. Song., and X. Dai. 2010. Length-Weight Relationships For Bigeye Tuna (Thunnus obesus), Yellowfin Tuna (Thunnus obesus) and Albacore (Thunnus alalunga) (Perciformes: Scrombrinae) In The Atlantic, Indian and Eastern Pacific Oceans. Vol. Sci. Pap. ICCAT, 65(2): 717-724

2009. Growth and Mortality Rates of Bigeye Tuna (Thunnus obesus) (Perciformis : Scrombinae) in Central Atlantic Oceans. College of Marine Science. Shanghai Ocean University. Cina. Vol 57 (1-2) : 79-88.

Zhu, G.P., X.J. Dai., L.M. Song., and L.X. Xu. 2011. Size at Sexual Maturity of Bigeye Tuna Thunnus obesus (Perciformes: scombridae) in the Tropical Waters: a Comparative Analysis. Shanghai Ocean University, College of Marine Sciences, The Key Laboratory of Shanghai Education Commission for Oceanic Fisheries Resources Exploitation, Shanghai 201306, China. Ministry of Education, The Key Laboratory of Sustainable Exploitation of Oceanic Fisheries Resources (Shanghai Ocean University), Shanghai 201306, China. Turkish Journal of Fisheries and Aquatic Sciences 11: 149-156 